\title{
Creative thinking as methodical category of foreign language learning
}

\author{
Aleksandr Victorovich Litvinov ${ }^{1 *}$ and Stanislav Leonidovich Bukovsky ${ }^{2}$ \\ ${ }^{1}$ Moscow State University of Psychology and Education, Chair of Foreign and Russian Philology; \\ Peoples' Friendship University of Russia, Department of Foreign Languages, Moscow, Russia \\ ${ }^{2}$ Russian State Agrarian University - Moscow Timiryazev Agricultural Academy, Foreign and \\ Russian Languages Department, Moscow, Russia
}

\begin{abstract}
This article is devoted to the development and improvement of the creative thinking approach of foreign language learning, namely speaking process. In that sense, the authors of the given article consider creative thinking as method and technique of foreign language learning and means of communicative competence development. The authors also describe the estimation system of the given method and its content in a form of methodical algorithm and theoretical principles of foreign language learning using creative thinking as an approach. The aim of the given article to develop a new approach for better development of foreign language communication, especially in skills of speaking, to be based on unique thinking as a technique in learning. The authors of the given article also developed and presented notion called "creativization" as methodical and theoretical category in foreign language learning process comprising some theoretical aspects of the given foreign language learning approach including its own specifics and conceptual points described in the given article. Creativization is also described by the authors of the given article as a technique in foreign language learning especially concerning speaking. The notion "creativization" presents concept ideas and basic principles of creative thinking approach in foreign language learning in a form of several methodical principles and theoretical aspects.
\end{abstract}

Keywords: creativization, speaking, approach, principles, communication, estimation, logic

\section{Introduction}

Understanding the main point of creativity and its consistent elements is the question laying at different psychological, pedagogical and philosophical theories, viewpoints and concepts.

Analyzing, in detail, psychological aspects, which are the most important for creativity development program understanding, we can conclude that, generally creativity is considered as activity in the situations of uncertainty directed at receiving of results, having novelty. Judging by this, creativity takes place in all cases, when a person has to act and make appropriate decisions in situations of the uncertainty of problem-solving ways.

*Corresponding author: alisal01@yandex.ru 


\section{Methods}

Before starting our research, we developed a theoretical basis for our research based on a new methodological principle. We called that principle the principle of learning process creativization. We consider this principle as the conceptual element for our research. According to this principle, creative thinking is considered as the means and method for students' communicative competence development in foreign language learning.

Creative thinking development is the necessary step for communicative competence formation. This process can be achieved by means of creative exercises. In that sense, creative thinking can be considered both as a method and as the aim of foreign language learning. Therefore, we analyze the notion "creativization" as the creation by a teacher such learning conditions under which creative thinking and communicative competence development can be carried out with the better way of learning process intensification.

In our viewpoint, the principle of learning process creativization includes the following aspects:

- forming of creative learning conditions;

- using of the exercises for creative thinking development (both in a form of drills, guided practice activities and communicative tasks);

- using creative thinking by students in a way of appropriate comprehension while solving of communicative task problems and foreign language speaking processes during the lesson.

This principle is also based on the following basic points:

1) concentration on students' independent learning;

2) recognition and rewarding of students' generated idea originality;

3) communicative orientation of learning.

The aim of the following principle is students' creative thinking development as a method of foreign language learning with the purpose of learning process intensification. In addition to that, we offer to highlight already known creative process stages that are considered as standard in psychology:

1. Preparation. Problem realizing, the first attempt appearance to find ways for solving problem. For that period logical thinking is more appreciated that allows indicating the problem in existing meanings.

2. Incubation. Temporary putting off the problem when a man, involved in doing something else without making any attempts for solving the problem, subconsciously continues to search for a definite decision [1]. And this period of time of waiting for the original idea appearance for problem solving is called "incubation period." In the sphere of creative ideas formulation this term is used in positive sense: when idea appears not consistently but suddenly [2].

3. Insight and further modification of appeared problem solving. This stage is carried out with the help of logical thinking. It also should be born in mind that, for students' creativity development it is necessary for a teacher to create the appropriate conditions in which a student can function as a highly creative personality.

\section{$3 \quad$ Results}

In our research we used the following estimation criteria: 
- $\quad 0$ points. Obvious names, simple titles, stating the class to which the drawn object belongs. These names consist of one word. For example: "Man", "Garden", "Mountains", etc.

- point. Simple descriptive titles. These names describe the specific properties of the drawn objects. As a rule, they express on the verbal level what we see in the picture.

- points. Figurative descriptive titles. Such names are somewhat unusual, poetic, figurative. They also reflect what is shown in the picture.

- $\quad$ points. Abstract, often philosophical (but adequate) names. These names express the essence of the picture, its deep inner meaning that goes beyond the image.

0 points - assessed as "unsatisfactory"; 1 point is assessed as "satisfactory"; 2 points "good"; 3 points - "excellent".

3 points - the maximum result of the assessment of creativity. In the process of performing the exercises, control is carried out according to three indicators of creativity (fluency, flexibility, originality), each of these components is assessed separately, after which the teacher summarizes the overall result, i.e. fluency -3 points, flexibility -3 points, originality -3 points, in total, 9 points for one lesson.

By the end of the semester, the teacher calculates the total number of student creativity points. For example, with a maximum of 18 points for each week, and multiplying by 15 weeks in the semester a student can get 270 points at the end of the semester.

Further, the total number of student creativity points is 270 (maximum), dividing by three with the result of 90 .

90 points - the maximum end result of the student's creativity at the end of the semester.

The table below is a comparative analysis of the pre-experimental and post-experimental sections in the experimental and control groups.

Table 1. Table of comparative analysis of pre-experimental and post-experimental sections in the experimental and control groups.

\begin{tabular}{|l|l|c|c|}
\hline \multirow{2}{*}{ Group } & \multirow{2}{*}{$\begin{array}{c}\text { Experimenta } \\
\mathbf{1} \text { criteria }\end{array}$} & $\begin{array}{c}\text { Pre-experimental section, } \\
\mathbf{\%}\end{array}$ & $\begin{array}{c}\text { Post-experimental section, } \\
\mathbf{\%}\end{array}$ \\
\hline \multirow{2}{*}{ EG } & \multirow{2}{*}{ fluency } & 30.5 & 84 \\
\cline { 3 - 4 } CG & \multirow{2}{*}{ flexibility } & 18.5 & 51 \\
\cline { 3 - 4 } EG & \multirow{2}{*}{ originality } & 35 & 70 \\
\cline { 3 - 4 } CG & 25.4 & 35 \\
\hline EG & 35 & 74 \\
\hline CG & & 34 & 43.5 \\
\hline
\end{tabular}

After analyzing the results of the pre-experimental and post-experimental sections, we see a significant increase in all tested indicators of the level of development of oral language skills among junior students of an economic university. The results are shown in Table 2 .

Table 2. Experiential learning comparative table.

\begin{tabular}{|l|c|c|}
\hline \multirow{2}{*}{ Parameters } & \multicolumn{2}{c|}{ Group } \\
\cline { 2 - 3 } & $\begin{array}{c}\text { Experimental } \\
\text { (EG) }\end{array}$ & $\begin{array}{c}\text { Control } \\
\text { (CG) }\end{array}$ \\
\hline $\begin{array}{l}\text { The total volume of the communicative act: the number of } \\
\text { replicas during the implemented communication }\end{array}$ & $\begin{array}{c}9 / 33 \\
3 \text { minutes }\end{array}$ & $\begin{array}{c}8 / 9 \\
2,5 \text { minutes }\end{array}$ \\
\hline $\begin{array}{l}\text { 1. Individual activity: the number of replicas of each with } \\
\text { an indication of the average duration of the replica sound }\end{array}$ & $\begin{array}{c}5 / 4,5 \\
20 \text { seconds }\end{array}$ & $\begin{array}{c}5 / 3,5 \\
25 \text { seconds }\end{array}$ \\
\hline $\begin{array}{l}\text { 2. Correctness of communication: the number of used } \\
\text { markers }\end{array}$ & $1 / 15$ & $0 / 1$ \\
\hline
\end{tabular}




\begin{tabular}{|l|l|l|}
\hline 3. Dynamism of communication & $1 / 1$ & $0 / 0$ \\
\hline 4. Representativeness of communication & $0 / 1$ & $0 / 0$ \\
\hline 5. Productivity (effectiveness) of communication & $1 / 1$ & $1 / 1$ \\
\hline $\begin{array}{l}\text { 6. Communication creativity (fluency, flexibility, } \\
\text { originality) }\end{array}$ & $2 / 3$ & $0 / 1$ \\
\hline Total points for additional parameters & $2 / 3$ & $1 / 1$ \\
\hline
\end{tabular}

The results obtained give grounds to assert that the set research tasks have been generally solved, and the hypothesis put forward has been confirmed. The data of the post-experimental final section confirm the possibility of a phased formation of the skills of oral foreign language professional communication by creative approach.

\section{Discussion}

According to P. Torrance $[3,4]$, creative thinking is connected with critical disadvantages comprehension, lack of knowledge and disharmony.

V.S. Urkevich also describes the second creativity type that appears by means of primarily high intellectual children's abilities [5].

Ponomarev I.A. states that creative abilities exist independently from the intellect [6].

The same idea is shared by E.P. Torrance, who believes that creative abilities start its functioning since achieving a definite intellectual level [7].

Dan Davies, Divya Jindal-Snape, Chris Collier, Rebecca Digby, Penny Hay \& Alan Howe offer to use even outdoor environments such as forest schools which as creative environments include providing freedom to explore using multiple senses and intelligences and space for individual learning styles to be recognized [8].

Also, creative environment can be observed in research of preschool education made by Cansu Yildiz \& Tulin Guler Yildiz. The result of their research reveals that high home environment quality makes a positive difference in creative thinking skills [9].

According to Enikő Orsolya Bereczki \& Andrea Kárpáti, teachers conceptualized creativity through addressing its chief components: process, product, person, and environment [10].

The same conception shared by E. de Bono, considering creativity by means of detailed analysis of problem-solving process [11].

Kupers E. \& van Dijk M. state that only if ones study the interactions between teachers and students more closely both qualitatively and quantitatively, one is able to distill what types of interactions foster or hinder creativity [12].

Dekker T.J. considers multiplicity as crucial factors of students' creativity development [13].

Markova A.K. emphasizes the following personality features allowing to be considered as creative one. They are: a) producing alternatives ability, b) ability for criticizing cliché, c) refusing from one-way, categorizing judgment [14].

Hooijdonk M., Mainhard T., Kroesbergen E.H. \& van Tartwijk J., besides creative fluency and originality, also add completeness and practicality on fact finding and problem finding [15].

Kipnis M. describes differences between creative and logical thinking:

1. Logical thinking is consistent while creative thinking has wider spectrum with additional role of logic activity.

2. According to logical thinking, each cognitive step should be correct while creative thinking pays attention only to the result of any activity. 
3. Logical thinking tends towards rapid cliché and categorized estimations while creative thinking tendency is to avoid possible standards during making exercises [16].

After giving comparisons between these two types of thinking, it is necessary to note the content of creative process itself.

From our viewpoint, creativity practical implementation in foreign language learning can be carried out under certain conditions and demands for learning process itself. These conditions include creation of positive psychological climate at the lesson and the climate of mutual trust and understanding.

\section{Conclusion}

In that sense, we can consider that, communicative competence development can be connected with creative thinking development, which is to be means for such activity at the lessons of foreign languages. In the situation with foreign language learning, foreign language in non-linguistic universities must promote student's creative personality development in the sphere of his future profession with abilities for easier involving in information research activity in foreign language, successfully putting into practice his foreign language skills in his professional activity.

\section{References}

1. A.G. Grezlov, Trening tvorchestva dlya shkolnikov i studentov [Creativity Training for pupils and students] (Peter Publisher, St. Petersburg, 2007)

2. M. Nelke, Metody tvorchestva [Creativity Techniques] (Omega-L, Smart Book, Moscow, 2009)

3. E.P. Torrance, Education and the creative potential (The University of Minnesota press, Minneapolis, 1963). https://doi.org/10.1177/001316446402400329

4. E.P. Torrance, Encouraging creativity in the classroom (William C. Brown Co Dubuque, 1970)

5. V.S. Urkevich, Odarennyi rebenok: illyuziya ili realnost: uchebnoe posobie dlya uchitelei [Gifted child: illusion or reality: textbook for teachers] (Moscow, 1996)

6. I.A. Ponomarev, Tvorcheskaya psikhologiya i pedagogika [Creative Psychology and Pedagogy] (Moscow, 1976)

7. E.P. Torrance, The nature of creativity as manifest in its testing, in R.W. Sternberg (ed), The nature of creativity (Cambridge, New York, 1965)

8. D. Davies, et al., Think Skills Creativ, 8, 80-91 (2013). https://doi.org/10.1016/j.tsc.2012.07.004

9. C. Yildiz, T.G. Yildiz, Think Skills Creativ, 39, 100795 (2021). https://doi.org/10.1016/j.tsc.2021.100795

10. E.O. Bereczki, A. Kárpáti, Think Skills Creativ, 39, 100791 (2021). https://doi.org/10.1016/j.tsc.2021.100791

11. E. de Bono, Shest shlyap myshleniya [The six hats of thinking] (Peter Publishing, St. Petersburg, 1997)

12. E. Kupers, M. van Dijk, Think Skills Creativ, 36, 100648 (2020). https://doi.org/10.1016/j.tsc.2020.100648 
13. T.J. Dekker, Think Skills Creativ, 37, 100701 (2020). https://doi.org/10.1016/j.tsc.2020.100701

14. A.K. Markova, Psikhologiya deyatelnosti uchitelya [Teacher Activity Psychology] (Education Publisher, Moscow, 1993)

15. M. Hooijdonk, et al., Think Skills Creativ, 37, 100665 (2020). https://doi.org/10.1016/j.tsc.2020.100665

16. M. Kipnis, Trenirovka intellekta: effektivnye stili obshcheniya i sposoby tvorcheskogo povedeniya. 60 luchshikh sposobov i uprazhnenii dlya razvitiya tvorcheskogo myshleniya [Training intellect: effective communicative styles and the ways of creative behavior. 60 best ways and exercises for creative thinking development] (AST Publishing, Moscow, 2009) 